ily running over in his mind the list of his lady acquaintances, to see if he could single out one who would be likely to be "in those parts," the Colonel with great alacrity obeyed the summons, and the Major leading the way, passed out upon the platform. The Colonel's height compelled him to stoop as his form emerged through the door, which seemed scarcely to admit of his egress, and as his tall presence loomed up before the astonished gaze of the lady who wished to see him, the Major introduced him to the virago as "Hon. Horace Greeley of the New York Tribune." With mouth wide open, eyes extended, and hands uplifted, the discomfitted "heroine" exclaimed: "That Horace! Wal, stranger, I reckon I'll have ter back out of that ere fight," and the old lady subsided into the dense crowd of spectators amid roars of laughter frum both sides. The Colonel took the joke with imperturbable good nature, and from that time forth, was familiarly addressed by his prison associates as "Greeley."

\title{
POWESHEIK, WAPASHASHEIK AND KISKEKOSH.
}

A CHAT WITH COLONEL TROWBRTDGE.

BY THE EDITOR.

These Indian chiefs belonged to the Musquaka or Fox tribe. Their villages, in 1837 , when I first settled in Iowa, vere on the banks of the Iowa River, in what is now Pleasant Valley and Iowa City Townships, Johnson County.

PowesheIK was of large size-his weight conld not have been less than 250 pounds-fat, heavy, lazy and a drunkard whenever he could get whisky, and that was frequently; but honest, brave and just. His word was sacred. A gift was also a sacred thing long to be remembered with gratitude. He was slow to arouse to active work, but when fully aroused, was a man of energy and power while the stimulus that awakened him remained. The leading qualities of his mind seemed to be truthfulness and a sense of justice. All in all, he was rather a noble specimen of the American savage. $\mathrm{H}_{0}$ was the chief of the tribe. 
'WAPASHASHEIK, the second in command, was tall and thin; inclined to justice, honesty and sobriety. He was a man of far less force of character than Powesheik, by whom he was controlled; managed his own village very well, but all weighty or difficult matters were referred to the head chief. Of him little more than this can be said.

KISKeковн was not a chief, but a prominent man-a war leader. A self-constituted leader of portions of the tribe; not recognized as a chief, but as a strong and influential man, and an aspirant for leadership. He was rather a remarkable Indian, but the very opposite of Poweshiek in many particulars. Tall, straight, active, a swift runner - of great muscular power-the master in every athletic test with his tribe, and possessed of the most perfect figure and physical development I ever saw. Was of sober habits, fluent in speech (to his people) and eloquent. A fine natural orator, he had, for a time, great influence with his tribe, but commanded less respect with the traders and settlers than his cotemporary chiefs, for in character he was cunning, sharp, dishonest, mean, treacherous, and a liar. Little good can be told of him.

These were the great men of the Fox Indians at that time. Powesheik was then about forty years of age, and Kiskekosh probably about ten years younger.

HOW POWESHEIK ADMINISTERS JUSTICE AND RULES HIS TRIBE.

One summer a horse had strayed or been stolen from a remote neighborhood. The owner follows his trail into the neighborhood of the Indian villages. Calls upon the trattlers in the vicinity of the villages, but can get no further folue to it. He suspects that it is in possession of the Indians. Calls upon Powesheik early in the morning, and through an rinterpreter states his case. The chief knows nothing of it, but will investigate it. Immediately he issues an order, iwhich is spread with great rapidity, that no man or person ishall leave the village until further ordered. Not a soul dared to, or did go. The owner describes his beast; is sent through the camp, with an escort, in search of it; finds and points it 
out very readily. The Indian owner is examined-i. $e$. the avowed owner-but can give no satisfactory explanation of his ownership. The horse is passed over to the white man, and the Indian made to pay him liberally for his trouble and expense in hunting him, which is assessed upon his annuity from government. The owner is thereupon dismissed satisfied, and the thief is now taken in hand by the chief and punished for his dishonesty.

Had the encampment or village been walled in, or sentinels posted, it would not have been more secure in retaining every denizen at home until the search was over, than was the imperious word of Powesheik to his people.

\section{JOHN GILBERT.}

John Gilbert-the trader among this tribe at this time-I knew well; made his acquaintance soon after my arrival, in 1837; became intimate with him, and, to a great extent, shared his confidence. His real name was John W. Prentice, a cousin of George D. Prentice, of the Louisville Journal. He was a remarkable man for the position he occupied. A fine scholar and an excellent business man. Far above the average of men in scholarly acquirements and business capacity. Was a native of the State of New York. Lost heavily in canal contracts. That, together with a train of other serious troubles, induced him to abandon his home at Lockport, N. Y., and to a change of name and business. He entered the service of the Green Bay Trading Company at some point in Michigan (then a territory). Learned the Indian language; secured the confidence of the company by his capacity, faithfulness and integrity; was sent to various points among the Indians to establish branch posts; in that capacity came among the Foxes on the Iowa. Died in March, 1839. A few years afterwards his remains were disinterred from their first resting place near his old trading house, by a few of his old friends, among whom were Eli Myers, S. H. McCróry, Phílip Clark, Henry Felkner, A. D. Stephens and others, and transferred to the village grave yard. It was our intention then, and for a long time afterward, to erect a suitable monument 
at his grave; but it was neglected from year to year, and was never done. Finally, some miscreant, for some purpose, perhaps for fire-wood, removed the wooden slabs from his grave, and among the rapidly multiplying graves of the now eity cemetery, his was lost. No one can now tell the exact spot where rests the ashes of the first white man that trod the soil of Johnson County.

\section{OFFICERS OF THE STATE HISTORICAL SOCIETY OF IOWA FOR THE YEAR 1868.}

President-Robert Hutchinson.

Vice Presidents-Prof. S. M. Fellows, Rev. Wm. Emonds, Hon. Elipalet Price, Anson Hart, Capt. Solomon Shepherd, Hon. John F. Dillon.

Correspondiny Secretury-Sanford W. Huff, M. D.

Recording Secretary-S. E. Paine.

Treasurer-H. S. Welton.

Librarian-C. T. Clark.

Board of Curators-Hon. Geo. W. McCleary, M. W. Davis, Frederick Lloyd, M. D., John P. Irish, Moses Bloom, Wm. Vogt, M. D., G. W. Dodder, Prof. S. S. Howell, Gov. S. J. Kirkwood, Col. S. C. Trowbridge, Walter Hoyt, Prof. E. M. Guffin, Henry Murray, M. D., Wm. Crum, Hon. F. H. Lee, Chas. W. Hobart, Hon. R. S. Finkbine.

President of the Board-Hon. Geo. W. McCleary.

Correction.-In the October Number, 1867 , page 959 , in the list of officers of the Iowa Institution for the Blind, General James L. Geddes' name is incorrectly printed Rev. instead of General. 
Copyright of Annals of Iowa is the property of State of Iowa, by \& through the State Historical Society of Iowa and its content may not be copied or emailed to multiple sites or posted to a listserv without the copyright holder's express written permission. However, users may print, download, or email articles for individual use. 